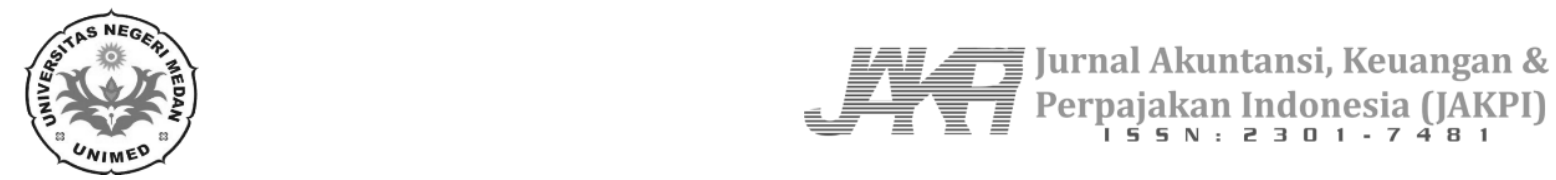

\title{
PENGARUH MEDIA PEMBELAJARAN (QUIPPER SCHOOL) TERHADAP HASIL BELAJAR SISWA AKUNTANSI DI SMK NEGERI 7 MEDAN
}

\author{
Ulfa Nurhayani, Weny Nurwendari, Choms Gary G.T Sibarani \\ Universitas Negeri Medan
}

\begin{abstract}
ABSTRAK
Penelitian ini bertujuan untuk meningkatkan Hasil Belajar Siswa Akuntansi kelas X SMK N 7 Medan Tahun Ajaran 2016/2017 dengan menggunakan media pembelajaran Quipper School. Target penelitian ini adalah untuk dijadikan kerangka dasar dalam mengembangkan media pembelajaranQuipper Schooluntuk meningkatkan Hasil Belajar Akuntansi. Metode penelitian yang digunakan adalah Quasi Experimental Nonequivalent Group Design. Penelitian ini dilaksanakan di SMK Negeri 7 Medan pada siswa kelas X menggunakan tekhnik purposive random sampling, diperoleh kelas XAk1 sejulah 40 siswa sebagai kelas eksperimen dan kelas XAk4 sejumlah 38 siswa sebagai kelas control. Pengumpulan data dalam penelitian ini menggunkan lembar observasi, pre-tes dan post-test. Tes terdiri dari 40 butir soal pilihan ganda untuk kemampuan dasar-dasar akuntansi perusahaan jasa. Tes diadakan sebelum siswa memperoleh perlakuan (pre-tes) dan sesudah siswa memperoleh perlakuan (post-test). Tekhnik analisis data yang digunakan adalaj uji normalitas, uji homogenitas, dan uji perbedaan rata-rata kelas eksperimen dan kelas control.Hasil penelitian menunjukkan bahwa kemampuan awal siswa kedua kelas tidak berbeda secara signifikan dibuktikan dengan uji kesamaan dua rata-rata pre-test. Terdapat perbedaan kemampuan siswa kelas eksperimen dan kelas control setelah diberi perlakuan berbeda dibuktikan dengan uji Homogenitas. Diperoleh (sig)....... Terdapat pengaruh peningkatan hasil belajar kelas X dengan quipper school dibuktikan dengan uji Anova satu jalur gain diperoleh (sig) $0.001<(\mathrm{sig}) 0.05$.
\end{abstract}

Key Words : Media Pembelajaran Akuntansi, Quipper School, Hasil Belajar Siswa Akuntansi 


\section{Pendahuluan}

Dewasa ini terjadi perubahan dalam berbagai aspek kehidupan masyarakat sebagai salah satu akibat dari perkembangan teknologi informasi dan komunikasi dan pemanfaatannya oleh manusia. Khusus dalam dunia pendidikan dampaknya sangat terasa saat ini dan kedepan, sehingga orang menyebutnya sebagai masa pengetahuan (knowledge age) dengan percepatan peningkatan pengetahuan yang luar biasa. Percepatan peningkatan pengetahuan ini didukung oleh penerapan media dan teknologi digital yang disebut dengan information super highway, informasi semakin cepat terdistribusi ke seluruh penjuru dunia.

Akibatnya, dunia pendidikan semakin penting dan dituntut untuk menjamin peserta didik memiliki keterampilan belajar dan berinovasi, keterampilan menggunakan teknologi dan media informasi, serta dapat bekerja, dan bertahan dengan menggunakan keterampilan untuk hidup (life skills).

Perkembangan teknologi informasi dan komunikasi yang sangat pesat mendorong berbagai lembaga pendidikan memanfaatkan sistem e-learning untuk meningkatkan efektivitas dan fleksibilitas pembelajaran. Keuntungan yang bisa diperoleh dengan e-learning adalah dalam hal fleksibilitasnya yaitu dapat diakses kapan saja dan dari mana saja, disamping itu materi yang dapat diperkaya dengan berbagai sumber belajar termasuk multimedia dengan cepat dapat diperbaharui oleh pengajar.

Pembelajaran e-learning adalah pembelajaran yang diterapkan di bidang pendidikan dalam bentuk dunia maya dengan internet. Dengan e-learning, peserta ajar (learner atau murid) tidak perlu duduk dengan manis di ruang kelas untuk menyimak setiap ucapan dari seorang guru secara langsung. $E$ learning juga dapat mempersingkat jadwal target waktu pembelajaran, dan tentu saja menghemat biaya yang harus dikeluarkan oleh sebuah program studi atau program pendidikan. Pembelajaran E-Learning juga dapat dimanfaatkan untuk memudahkan siswa dalam memahami akuntansi. Akuntansi merupakan ilmu yang sudah mulai diajarkan kepada para siswa bahkan sejak tingkat Sekolah Menengah Pertama (SMP). Meskipun ilmu akuntansi yang diberikan tidak terlalu dalam, namun para siswa seharusnya sudah memiliki bekal pengetahuan dan keterampilan dasar mengenai ilmu akuntansi tersebut.

Mata pelajaran Akuntansi merupakan salah satu mata pelajaran yang harus dikuasai oleh siswa Akuntansi SMK. Mata pelajaran Akuntansi memiliki karakteristik khusus yang membedakannya dengan mata pelajaran yang lain. Salah satu kekhususan itu adalah selain menghendaki pemahaman terhadap konsep pelajaran tersebut juga menuntut praktek dan retensi karena ada bagian-bagian pelajaran yang harus dikuasai melalui ingatan.

Akuntansi dapat diartikan seperangkat pengetahuan yang mempelajari perekayasaan penyediaan jasa berupa informasi keuangan kuantitatif suatu unit organisasi dan cara penyampaian (pelaporan) informasi tersebut kepada pihakyang berkepentingan untuk dijadikan dasar pengambilan keputusan ekonomik. Pengambilan keputusan biasanya memerlukan informasi untuk menyakinkan bahwa harapanharapannya cukup pasti akan terealisasi. Salah satu informasi yang penting dalam dunia usaha maupun dalam kehidupan sehari-hari adalah informasi keuangan sebagai dasar pertimbangan untuk pengambilan keputusan tertentu. Unsur penting lain adalah perlunya informasi keuangan untuk pertanggungjawaban. Akuntansi merupakan satu pengetahuan yang banyak menawarkan tantangan intelektual mengingat akuntansi dapat digunakan sebagai alat untuk mencapai tujuan yang lebih luas. Akan tetapi, perlu ditekankan bahwa akuntansi bukan semata-mata keterampilan teknis atau proses pencatatan. Akuntansi melibatkan pula proses penalaran dan perancangan dengan mempertimbangkan faktor lingkungan tempat akuntansi akan diterapkan. Akuntansi merupakan keahlian khusus yang bersifat melayani masyarakat sehingga faktor sosial, etika, dan moral juga terlibat di dalamnya, faktor tersebut menjadi penting khususnya kalau akuntansi diarahkan untuk mempertanggungjawabkan pengelolaan sumber ekonomi yang menguasai hajat hidup orang banyak.

Latar belakang pemilihan topik penelitian ini adalah karena masih banyak siswa yang mengalami kesulitan dalam belajar ilmu akuntansi, terutama saat siswa tersebut baru duduk di tingkat Sekolah Menengah Kejuruan (SMK) dan berada dijurusan Akuntansi. Kesulitan siswa antara lain, siswa masih kurang dapat mengerjakan tugas, ulangan dan ujian dengan percaya diri, tidak memahami dengan jelas apa yang disampaikan oleh guru, Disamping itu juga siswa tidak dapat memanfaatkan buku pegangan akuntansi yang disediakan sekolah secara maximal.

Penguasaan siswa terhadap mata pelajaran akuntansi dapat dilihat dari kemampuan dalam melakukan pembukuan. Tidak hanya itu secara nasional penguasaan siswa terhadap mata pelajaran tersebut juga dapat dilihat dari hasil ujian nasional dimana berdasarkan hasil pengamatan masih berada di bawah kriteria ketuntasan minimal (KKM).

Vol : 8, No:2, 2020 
Dari hasil penelititan awal yang dilakukan di SMK Negeri 7 Medan menunjukkan bahwa hasil belajar siswa pada mata pelajaran akuntansi masih dikategorikan rendah. Hal ini dapat dilihat dari data siswa di SMK Negeri 7 Medan masih banyak yang memperoleh nilai rendah pada mata pelajaran akuntansi sehingga tidak mencapai nilai Kriteria Ketuntasan Minimal (KKM) yang ditetapkan untuk mata pelajaran akuntansi di sekolah ini yakni sebesar 70,00. Hal ini dibuktikan dari hasil belajar mata pelajaran akuntansi selama 5 tahun terakhir, seperti yang terlihat pada tabel 1.1 berikut ini:

\section{Tabel 1.1 Perolehan Rata-Rata Nilai Ujian Akhir Semester Akuntansi Lima Tahun Terakhir Di SMK Negeri 7 Medan}

\begin{tabular}{|l|l|l|l|}
\hline NO & MATA KULIAH & TAHUN AJARAN & NILAI RATA-RATA UJIAN FORMATIF \\
\hline 1. & Akuntansi & $2009 / 2010$ & 64,00 \\
\hline 2. & Akuntansi & $2010 / 2011$ & 63,74 \\
\hline 3. & Akuntansi & $2011 / 2012$ & 65,21 \\
\hline 4. & Akuntansi & $2012 / 2013$ & 66,35 \\
\hline 5. & Akuntansi & $2013 / 2014$ & 69,61 \\
\hline
\end{tabular}

(Sumber: Data Tata Usaha SMK Negeri 7 Medan)

Dari Tabel 1.1 di atas dapat diperhatikan bahwa perolehan hasil belajar mata pelajaran Akuntansi masih cenderung kurang memuaskan. Hal ini dapat disebabkan oleh penyampaian materi secara teori oleh guru lewat ceramah, demonstrasi, latihan dan mengadakan tugas-tugas. Media pembelajaran yang digunakan masih konvensional yaitu menggunakan papan tulis, buku pelajaran dan modul pelajaran, akibatnya banyak siswa kurang serius mengikuti materi akuntansi keuangan karena media yang digunakan dalam penyampaian masih terbatas. Pada akhirnya berpengaruh kepada penguasaan materi mata pelajaran Akuntansi yang akan berpengaruh pada praktisi dari lulusan SMK yang diharapkan akan mampubersaing dalam dunia pasar kerja.Menurut Daryanto (2012) bahwa "kurang aktif dan rendahnya hasil belajar siswa dipengaruhi oleh kurang terlibatnya siswa dalam kegiatan pembelajaran dan penggunaan media pembelajaran yang kurang tepat".

Untuk mengatasi adanya kesenjangan tersebut, maka salah satu hal yang dapat diterapkan dalam menyampaikan materi mata pelajaran Akuntansi adalah menyesuaikan media pembelajaran yang akan digunakan dalam proses pembelajaran.

Oleh sebab itu peneliti tertarik untuk melakukan penelitian bagaimana pengaruh Quipper School terhadap hasil belajar siswa di sekolah SMK Negeri 7 Medan. Penelitian ini penting karena quipper schoo lmenjadi sebuah cara baru belajar kreatif untuk memudahkan siswa memahami akuntansi. Media pembelajaran ini patut diacungkan jempol karena pilihan guru yang ditawarkan kepada siswa sangat bervariasi meliputi semua bidang studi mulai tingkat SMP hingga SMU dan akuntansi tentunya. Sehingga Quipper School menjadi media pembelajaran yang baik dibanding media pembelajaran online lainnya.Kegiatan belajar menggunakan media internet dengan aplikasi Quipper School dapat juga disesuaikan dengan waktu yang dimiliki siswa, siswa dapat belajar kapan dan dimana saja, belajar akan menjadi sangat menyenangkan, tidak membosankandan menarik minat siswa untuk belajar akuntansi. Inilah added value Quipper School yang tidak dimiliki media pembelajaran lain.

Quipper School Indonesia memberikan kemudahan bagi guru dalam memberikan tugas kepada siswa secara online dan siswa dapat mengerjakannya (sekaligus mempelajari topik mata pelajaran yang berkaitan dengan tugas tersebut) baik di dalam maupun di luar kelas melalui perangkat mereka masingmasing yang terkoneksi dengan internet.

Setelah para siswa mengerjakan serta mengumpulkan tugasnya, sistem penilaian yang tersedia pada platform Quipper School Indonesia akan melakukan analisis data secara sederhana namun canggih yang akan membantu para Guru dalam mendapatkan gambaran yang jelas tentang pencapaian siswa. Tentu saja sistem penilaian hanya bersifat membantu, setelah guru secara manual memasukkan data soal dan jawabannya. Sehingga sistem penilaian bertugas mencocokkan antara jawaban dari siswa dengan kunci jawaban versi guru.

Para guru akan mendapatkan laporan mengenai seberapa baik sang siswa dalam menguasai mata pelajaran tertentu, bagaimanakah kemajuan belajar setiap siswa, mengetahui keunggulan atau potensi setiap siswa, siapa yang mendapat nilai tertinggi, dan lainnya. Melalui gambaran tentang pencapaian ini, para siswa pada saat itu juga akan memperoleh umpan balik mengenai hal-hal yang perlu diperbaiki terkait penguasaan terhadap suatu topik materi pelajaran tertentu.

Selama hampir setahun beroperasi di Indonesia, Quipper School Indonesia masih menggratiskan 
layanan dan konten yang disediakannya. Bagaimanapun, kedepannya Quipper School Indonesia berencana akan menyediakan fitur dan konten premium berbayar seperti online tutoring (les online) dan konten untuk persiapan Ujian Nasional (UN).

Sejauh ini pengguna yang sudah mendaftar di Quipper School Indonesia yaitu lebih dari 50.000 guru dan lebih dari 250.000 siswa. Namun, dari akumulasi jumlah guru dan siswa tersebut, baru 60 persen yang menjadi pengguna aktif bulanan. Para guru dan siswa ini bersumber dari sekitar 10.000 sekolah (dengan perbandingan SMA 70 persen dan SMP 30 persen). Setiap kelas online dalam Quipper School Indonesia sendiri dapat menampung hingga 60 siswa, tetapi para guru masih bisa membuat kelas online sebanyak-banyaknya sesuai kebutuhan.

Apabila dalam proses pembelajaran dapat menyenangkan, melalui penggunaan media pembelajaran yang tepat maka siswa akan merasa lebih senang dan tidak bosan dalam mengikuti kegiatan pembelajaran akuntansi sehingga tidak ada lagi siswa yang tidak tuntas dalam pelajaran akuntansi. Dan pada akhirnya akan dapat membangkitkan prestasi belajar siswa.

\section{Kerangka Teoritis Dan Pengembangan Hipotesis}

\subsection{Hasil belajar akuntansi}

Pendidikan dan pengajaran dikatakan berhasil apabila ada perubahan-perubahan yang terlihat pada diri anak didikyang merupakan akibat dari proses belajar yang dialaminya. Setidak-tidaknya apa yang dicapai oleh anak didik merupakan proses yang ditempuhnya melalui program dan kegiatan yang dirancang dan dilaksanakan oleh tenaga didik dalam proses mengajarnya.

Hasil belajar akuntansi merupakan proses kognitif. Hasil belajar akuntansi terdiri dari informasi verbal, keterampilan intelek, keterampilan motorik, sikap dan siasat kognitif.

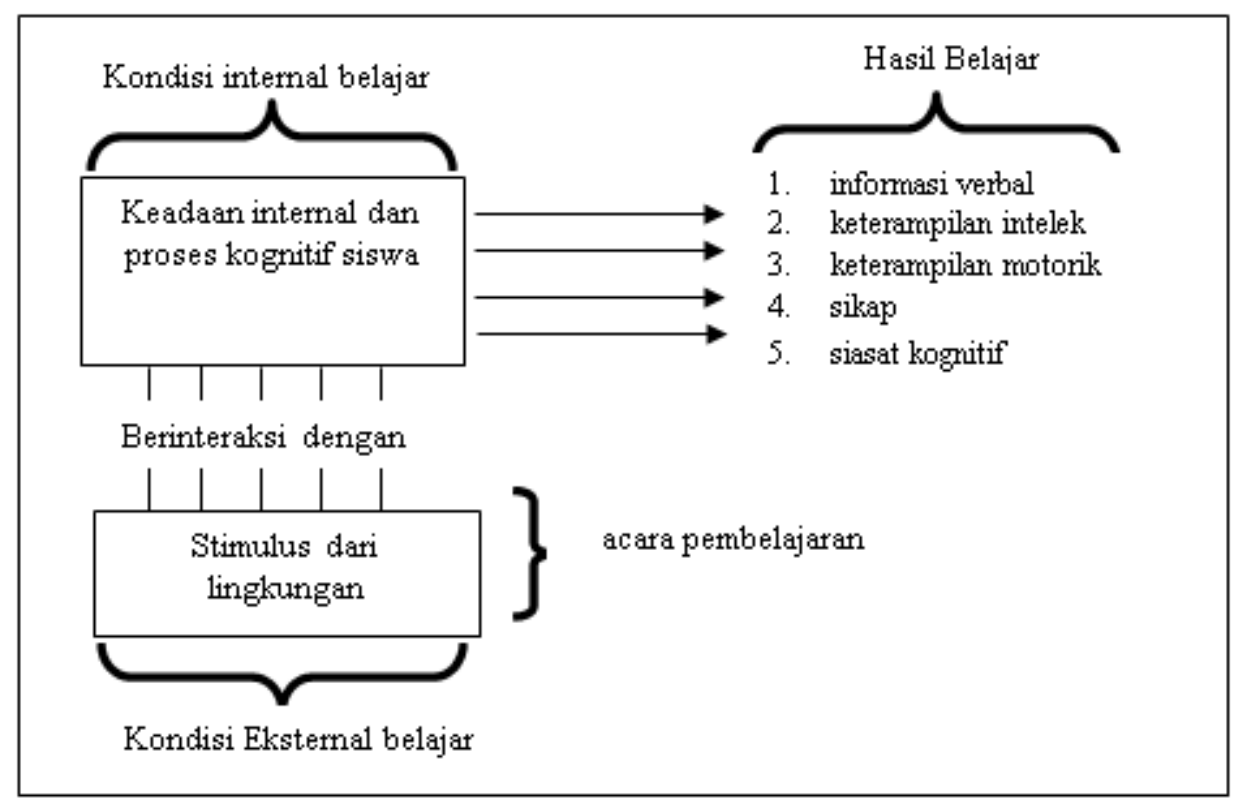

Gambar 2.1

Komponen Esensial Belajar dan Pembelajaran

Merujuk pemikiran Gagne (dalam Dimyati dan Mudjiono, 2009: 5), hasil belajar akuntansi berupa:

1. Informasi verbal yaitu kapabilitas mengungkap pengetahuan dalam bentuk bahasa, baik lisan maupun tertulis.

2. Keterampilan intelektual adalah kecakapan yang berfungsi untuk berhubungan dengan lingkungan hidup serta mempresentasikan konsep dan lambang.

3. Strategi kognitif adalah kemampuan menyalurkan dan mengarahkan aktivitas kognitifnya sendiri. 
4. Keterampilan motorik adalah kemampuan melakukan serangkaian gerak jasmanidalam urusan dan koordinasi, sehingga terwujud otomatisme gerak jasmani.

5. Sikap adalah kemampuan menerima atau menolak obyek berdasarkan penilaian terhadap obyek tersebut.

Menurut Sudjana (2009:22) mengatakan bahwa "hasil belajar akuntansi adalah kemampuankemampuan yang telah dimiliki siswa setelah ia menerima pengalaman belajarnya". Penguasaan hasil belajar akuntansi seseorang dapat dilihat dari perilakunya, baik perilaku penguasaan, pengetahuan, keterampilan berpikir maupun keterampiilan motorik.Pada umumnya hasil belajar akuntansi dan tingkah laku penguasaan materi pengajaran diukur dengan penelitian. Hasil belajar akuntansi biasanya diperlihatkan setelah anak didik menempuh kegiatan belajarnya dalam proses belajar mengajar.

Berdasarkan uraian diatas, dapat disimpulkan bahwa hasil belajar akuntansi adalah suatu perubahan yang terjadi pada diri siswa yang diperoleh siswa dari aktivitas belajar dan yang dapat diukur melalui proses evaluasi dan penelitian, dan diamati dari perilakunya, baik perilaku penguasaan, pengetahuan, keterampilan berpikir maupun keterampilan motorik.

Hasil belajar akuntansi yang dicapai anak didik merupakan hasil interaksi dari berbagai faktor yang mempengaruhinya baik itu dari dalam diri anak didik tersebut yang meliputi kemampuan yang dimiliki, motivasi belajar, minat dan perhatian, sikap dan kebiasaan belajar, ketekunan, sosial ekonomi, faktor fisik dan psikis, sedangkan faktor dari luar diri anak didik yaitu faktor lingkungan. Menurut Slameto (2010: 54), faktor-faktor yang mempengaruhi hasil belajar akuntansi adalah:

1. Faktor internal merupakan faktor yang ada dalam diri individu.

Faktor internal dibagi dalam tiga faktor, yaitu:

a. Faktor jasmaniah yang terdiri dari: faktor kesehatan, cacat tubuh;

b. Faktor psikologis yang terdiri dari: intelligensi, perhatian, minat, bakat, motif, kematangan, kesiapan;

c. Faktor kelelahan yang terdiri dari: kelelahan jasmani dan kelelahan rohani.

2. Faktor ekstern merupakan faktor yang ada dari luar individu.

Faktor ekstern dikelompokan ke dalam tiga faktor, yaitu:

a. Faktor keluarga yang terdiri dari: cara orang tua mendidik, relasi antara anggota keluarga, suasana rumah, keadaan ekonomi keluarga, pengertian orang tua, latar belakang kebudayaan;

b. Faktor sekolah yang terdiri dari: metode mengajar, kurikulum, relasi guru dengan siswa, relasi siswa dengan siswa, disiplin sekolah, alat pelajaran, waktu sekolah, standar pelajaran di atas ukuran, keadaan gedung, metode belajar, tugas rumah;

c. Faktor masyarakat yang terdiri dari: kegiatan siswa dalam masyarakat, mass media, teman gaul, bentuk kehidupan masyarakat.

Dari pendapat di atas, dapat disimpulkan bahwa faktor-faktor yang mempengaruhi hasil belajar akuntansi siswa adalah faktor internal siswa antara lain kemampuan yang dimiliki siswa tentang materi yang akan disampaikan, sedangkan faktor ekternal antara lain metode pembelajaran yang digunakan guru di dalam proses belajar mengajar.

Belajar Akuntansi merupakan suatu aktivitas yang dimaksudkan untuk memperdalam penguasaan siswa dalam bidang akuntansi melalui kegiatan belajar mengajar dikelas.Menurut Weygandt dkk (2011: 28) bahwa "Accounting is the information system that identifies, records, and communicates the economic events of an organization to interested users". Akuntansi merupakan sistem informasi yang mengidentifikasi, mencatat dan menginformasikan kondisi ekonomi dalam suatu perusahaan kepada pihak-pihak yang membutuhkannya.

Sedangkan Harahap (2012: 5) mendefinisikan Akuntansi adalah suatu kegiatan jasa. Fungsinya adalah memberikan informasi kuantitatif, umumnya dalam ukuran uang, mengenai suatu badan ekonomi yang dimaksudkan untuk digunakan dalam pengambilan keputusan ekonomi sebagai dasar memilih diantara beberapa alternatif.

Berdasarkan pendapat diatas, maka dapat disimpulkan bahwa akuntansi sebagai suatu kegiatan jasa tentang informasi keuangan suatu organisasi. Dengan adanya informasi tersebut dapat dilihat posisi keuangan suatu organisasi beserta perubahan yang terjadi didalamnya sehingga dapat digunakan oleh pihak-pihak yang berkepentingan untuk mengambil suatu keputusan dan tujuan ekonomi lainnya.

Maka hasil belajar akuntansi akuntansi adalah kemampuan yang diperoleh siswa baik secara individu maupun kelompok dari proses belajar mengajar akuntansi yang dinilai melalui evaluasi. Dari hasil belajar akuntansi akuntansi tersebut dapat dilihat suatu perubahan yang terjadi pada diri siswa 
sehingga siswa dapat mengaitkan setiap bab materi dan kerampilan motorik dapat mengaplikasikan ilmu akuntansi di dalam kehidupan sehari-hari sebagai hasil dari proses pembelajaran yang dapat diukur dan diamati.

\subsection{Pengertian Media Pembelajaran}

Media pembelajaran adalah segala sesuatu (alat, bahan, atau perangkat) yang digunakan dalam proses pembelajaran untuk menyampaikan pesan atau informasi sehingga dapat merangsang pikiran, perhatian, dan minat siswa demi tercapainya tujuan instruksional ((Asnewastari, 2006:25) Hal tersebut senda dengan Asror (2007:3) bahwa media pembelajaran merupakan segala sesuatu yang dapat digunakan untuk menyalurkan pesan (bahan pembelajaran), sehingga dapat merangsang perhatian, minat, pikiran dan perasaan siswa dalam kegiatan belajar untuk mencapai tujuan belajar. Diperkuat lagi oelah Purnama (2009:95) bahwa media adalah sesuatu yang berfungsi sebagai alat bantu belajar mahasiswa sehingga mahasiswa dapat lebih mudah dalam memahami pelajaran. Oleh sebab itu media pembelajaran merupakan salah satu faktor external yang berpengaruh terhadap keberhasilan kegiatan pembelajaran. Secara umum manfaat media pembelajaran adalah memperlancar interaksi antara guru dan siswa sehingga kegiatan pembelajran lebih efektif dan efisien (Hanum, 2013).

Berdasarkan dimensinya, media pembelajaran dapat dibedakan menjadi dua macam, yaitu:

a. Media Dua Dimensi

Media dua dimensi sering disebut media grafis, media dua dimensi adalah madia yang memiliki ukuran panjang dan lebar. Grafis sebagai media pengajaran dapat mengkombinasikan fakta-fakta, gagasan-gagasan secara jelas dan kuat melalui perpaduan antara ungkapan atau grafik. Kata-kata dan angka-angka dipergunakan sebagai judul dan penjelasan kepada grafik, bagan, diagram, poster, kartun dan komik. Sedangkan sketsa, lambang bahkan foto digunakan untuk mengartikan fakta, pengertian dan gagasan yang pada hakikatnya sebagai penyajian grafis. Contoh media dua dimensi (media grafis), yaitu:

- Bagan, yaitu kombinasi antara media grafis dan gambar foto yang dirancang untuk memvisualisasikan secara logis dan teratur mengeai fakta pokok atas gagasan. Fungsi bagan adalah untuk menunjukkan hubungan, perbandingan, jumlah relative, perkembangan, proses, klasifikasi dan organisasi.

- Diagram, yaitu suatu gambaran sederhana yang dirancang untuk memperlihatkan hubungan timbal balik terutama dengan garis-garis.

- Grafik, yaitu penyajian data berangka, Grafik merupakan keterpaduan yang lebih menarik dengan sejumlah tabulasi data yang tersusun dengan baik. Tujuan dalam grafik adalah memperlihatkan perbandingan, informasi kualitatif dengan cepat serta sederhana. Bebrapa macam grafik diantaranya yaitu grafik garis, batang, lingkran dan piring dan grafik.

b. Media Tiga Dimensi

Media tiga dimensi yaitu media yang mempunyai panjang, lebar dan isi. Media tiga dimensi yang sering dipakai adalah model dan boneka.

Dalam perkembangannya, media pembelajaran mengikuti perkembangan tekhnologi. Berdasarkan perkembangan tekhnologi tersebut, media pembelajaran dikelompokkan kedalam empat kelompok yaitu:

1. Media Hasil Tekhnologi

Tekhnologi cetak adalah cara untuk menghasilkan atau menyampaikan materi, seperti buku dan materi visual statis terutama melalui proses percetakan mekanis atau photografis. Kelompok media hasil tekhnologi cetak antara lain : teks, grafik, foto atau represntasi fotografik.

2. Media hasil tekhnologi audio visual

Tekhnologi audio visual menyampaikan materi dengan menggunakan mesin-mesin mekanis dan elektronis untuk menyajikan pesan-pesan audio visual penyajian pengajaran secara audio visual jelas bercirikan pemakaian perangkat keras selama proses pembelajaran, seperti, mesin proyektor film, tape rekorder, proyektor visual yang lebar.

3. Media hasil tekhnologi yang berdasarkan komputer

4. Teknologi berbasis computer merupakan cara menghasilkan atau menyampaikan materi dengan menggunakan sumber-sumber yang berbasis micro-processor. Berbagai aplikasi tekhnologi berbasis komputer dalam pembelajaran umumnya dikeal sebagai computer 
assisted instruction aplikasi tersbut apabila dilihat dari cara penyajian materi secara bertahap, drills end practice latihan unutk membantu siswa menguasai materi yang telah dipelajari sebelumnya, permainan dan simulasi (latihan untuk mengaplikasian pengetahuan dan keterampilan yang baru dipelajari) dari dan basis data (sumber yang dapat membantu siswa menambah informasi dan pengetahuan sesuai dengan keinginan masing-masing). Karakteristik media hasil tekhnologi yang berdasarkan komputer:
a. Dapat digunakan secara acak, non sekuensial, atau secaralinier
b. Dapat digunakan sesuai keinginan siswa atau perancang
c. Gagasan disajikan dalam gaya abstrak dengan simbol dan grafik
d. Berorientasi pada siswa dan melibatkan interaktifitas siswa yang tinggi.

5. Media hasil gabungan tekhnologi cetak dan tekhnologi komputer

Tekhnologi gabungan adalah cara untuk menghasilakn dan menyampaikan materi yang menggabungkan pemakaian beberapa bentuk media yang dikendalikan komputer. Komputer yang memiliki kemampuan yang hebat seperti jumah random accses memory yang besar, hard disk yang besar, dan monitor yang beresolusi tinggi ditambah dengan paralel (alat-alat tambahan) seperti : video disk player, perangkat keras untuk bergabung dalam suatu jaringan dan sistem audio. Keunggulan penggunaan media hasil gabungan tekhnologi cetak dan komputer antara lain adalah sebagai berikut:

a. Dapat digunakan secara acak

b. Dapat digunakan sesuai keinginan siswa, bukan saja direncakan dan diinginkan oleh perancangnya

c. Gagasan disajikan secara realistik sesuai dengan pengalaman siswa, menurut apa yang relevan dengan siswa dan dibawah pengendalian siswa

d. Prinsip ilmu kognitif dan kontruktifisme ditetapkan dalam pengembangan dan penggunaan pelajaran

e. Pembelajaran ditata dan terpusat pada lingkup kognitif sehingga pengetahuan dikuasai jika pengetahuan itu digunakan

f. Bahan-bahan pelajaran melibatkan interaktif siswa

g. Bahan-bahan pelajaran memadukan kata dan visual dari berbagai sumber.

Dapat disimpulkan bahwa keunggulan penggunaan media pembelajaran ialah memperjelas penyajian informasi dari guru ke siswa, mengatasi permasalahan keterbataan ruang, meningkatkan keaktifan siswa dalm proses pembelajaran.

\subsection{Pengertian Quipper School}

Quipper School Didirikan oleh Masayuki Watanabe di London pada Desember 2010, Quipper School merupakan layanan e-learning gratis yang diciptakan demi mempermudah tugas dan menghemat waktu para pendidik, khususnya dalam hal pemberian tugas / PR / latihan soal, bahkan ujian di kelas kepada peserta didik. Quipper School menyediakan materi pelajaran dan soal, terdiri atas ribuan topik untuk mata pelajaran Bahasa Indonesia, Bahasa Inggris, Matematika, IPA (Biologi, Fisika, Kimia), dan IPS (Geografi, Sejarah, Sosiologi, dan Ekonomi-Akuntansi), kelas X, XI, dan XII.

Quipper School merupakan startup pendidikan yang menyediakan dua layanan utama:

a. Pertama, Quipper School Learn sebuah portal khusus siswa dimana mereka bisa mengakses atau membaca materi pelajaran, menjawab soal, mengirimkan pesan ke guru, dan melihat performa belajar teman sekelasnya.

b. Kedua, Quipper School Link sebuah portal khusus untuk guru dimana mereka dapat menyiapkan tugas, melihat perkembangan siswa, mengirim pesan ke siswa, mengelola kelas, dan membuat kelas online.

- Secara teknis, melalui Quipper School Indonesia, guru dapat memberikan tugas kepada siswa secara online dan siswa dapat mengerjakannya (sekaligus mempelajari topik mata pelajaran yang berkaitan dengan tugas tersebut) baik di dalam maupun di luar kelas melalui perangkat mereka masing-masing yang terkoneksi dengan internet.

- Setelah para siswa mengerjakan serta mengumpulkan tugasnya, sistem penilaian yang tersedia pada platform Quipper School Indonesia akan melakukan analisis data secara sederhana namun 
canggih yang akan membantu para Guru dalam mendapatkan gambaran yang jelas tentang pencapaian siswa. Tentu saja sistem penilaian hanya bersifat membantu, setelah guru secara manual memasukkan data soal dan jawabannya. Sehingga sistem penilaian bertugas mencocokkan antara jawaban dari siswa dengan kunci jawaban versi guru.

- Para guru akan mendapatkan laporan mengenai seberapa baik sang siswa dalam menguasai mata pelajaran tertentu, bagaimanakah kemajuan belajar setiap siswa, mengetahui keunggulan atau potensi setiap siswa, siapa yang mendapat nilai tertinggi, dan lainnya. Melalui gambaran tentang pencapaian ini, para siswa pada saat itu juga akan memperoleh umpan balik mengenai hal-hal yang perlu diperbaiki terkait penguasaan terhadap suatu topik materi pelajaran tertentu.

Melalui Quipper School, seorang pendidik juga dapat:

1. Memantau kegiatan belajar para siswa (nilai tugas / PR siswa)

2. Melihat analisa data/grafik perkembangan siswa.

3. Melihat analisa topik mana yang sudah atau belum dikuasai oleh siswa

4. Mengirimkan pesan pribadi / menanggapi pertanyaan siswa

5. Membuat pengumuman untuk siswa

6. Mencetak (print) hasil nilai siswa

\subsection{Kerangka Berpikir}

Tahapan dalam penelitian ini terdiri dari:

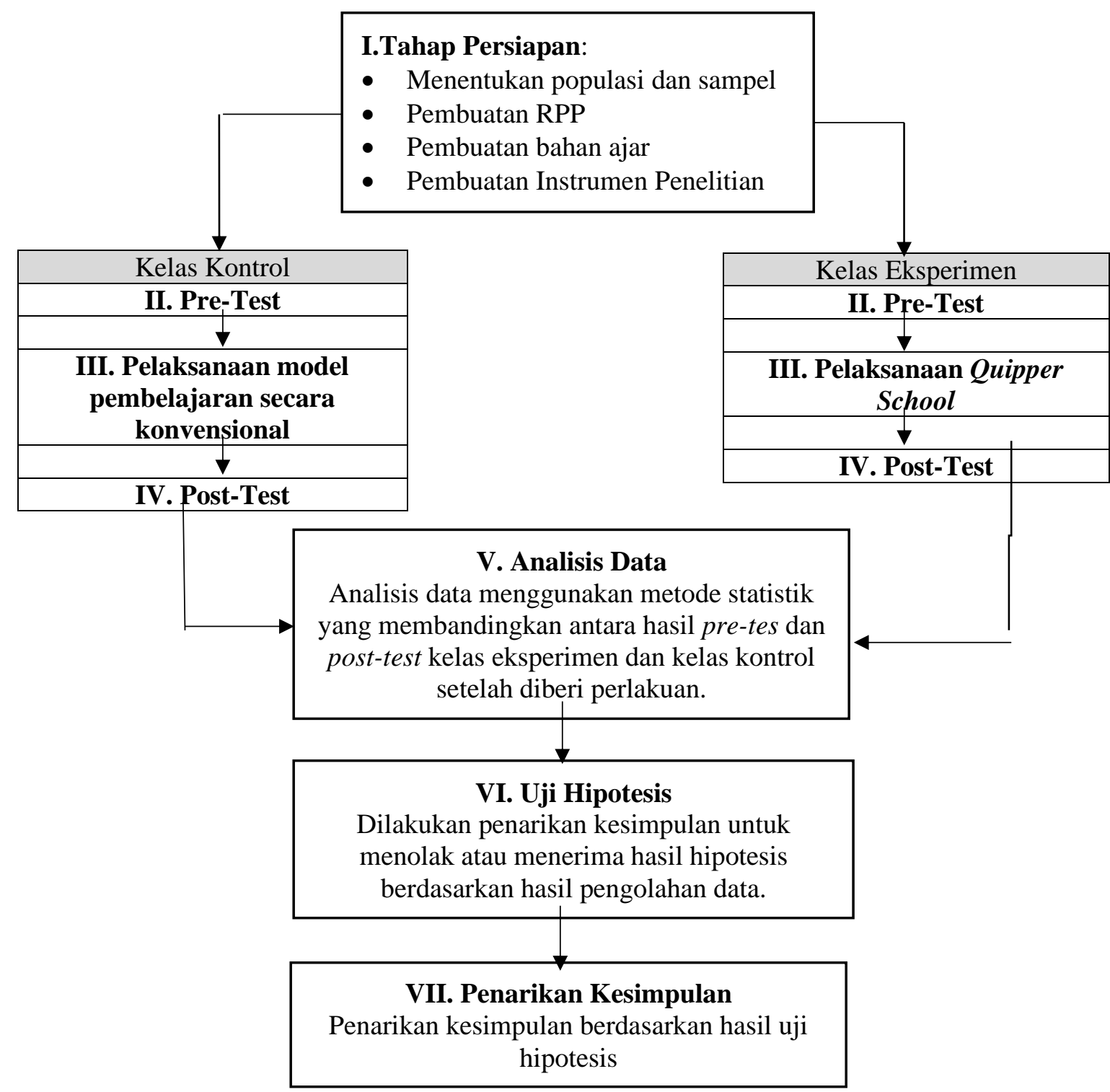




\section{Gambar 2.3 Tahapan Penelitian}

\subsection{Rancangan Penelitian}

Rancangan penelitian dalam penelitian ini adalah:

Kerangka penelitian dalam penelitian ini ada lah sebagai berikut:

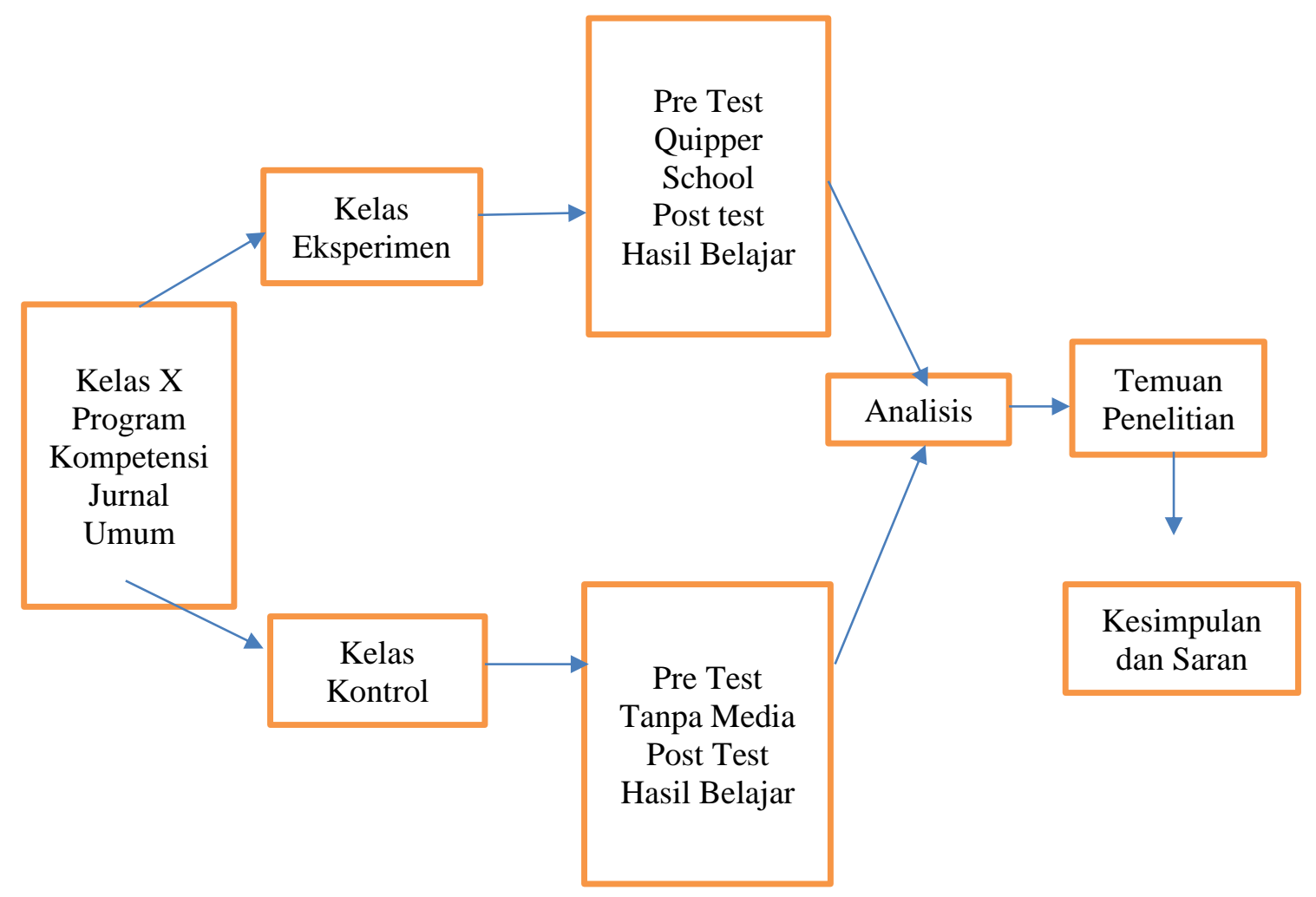

Gambar 2.3 Rancangan Penelitian

\subsection{Hipotesis}

Diduga bahwa ada pengaruh media pembelajaran Quipper School terhadap prestasi belajar Akuntansi siswa kelas X di SMK N 7 Medan.

\subsection{Teknik Analisis Data}

Untuk mendapatkan instrumen yang berkualitas dapat ditinjau dari beberapa hal diantaranya uji validitas, uji reliabilitas, uji indeks kesukaran, uji daya pembeda.

\subsubsection{Validitas Instrumen}

Validitas adalah suatu ukuran yang menunjukkan tingkat-tingkat kevalidan atau kesahihan suatu intrumen (Arikunto, 2012:59). Sebuah tes dikatakan valid apabila mempunyai dukungan yang besar terhadap skot total. Untuk mengetahui validitas item soal digunakan rumus korelasi product moment. Menurut Arikunto (Arikunto, 2012:72) yaitu : 
Keterangan:

$$
r_{\mathrm{xy}}=\frac{\mathrm{n} \sum \mathrm{xy}-\left(\sum \mathrm{x}\right)\left(\sum \mathrm{y}\right)}{\sqrt{\left(\mathrm{n} \sum \mathrm{x}^{2}-\left(\sum \mathrm{x}\right)^{2}\right)\left(\mathrm{n} \sum \mathrm{y}^{2}-\left(\sum \mathrm{y}\right)^{2}\right)}}
$$

$\mathrm{r}_{\mathrm{xy}}=$ koefisien korelasi (koefisien validitas).

$\mathrm{n} \quad=$ jumlah subjek

$\sum \mathrm{x}=$ jumlah skor setiap butir soal (jawaban yang benar)

$\sum x^{2}=$ jumlah kuadrat dari skor setiap butir soal

$\sum \mathrm{y}=$ jumlah skor total

$\sum \mathrm{y}^{2}=$ jumlah kuadrat skor total

Hasil perhitungan berdasarkan rumus korelasi diinterpretasikan dalam nilai kuantitatif (Arikunto 2012:89) sebagai berikut:

Tabel 3.1

Interpretasi Nilai Koefisien Validasi

\begin{aligned} Besar nilai $\mathrm{r}_{\mathrm{xy}} & \multicolumn{1}{c}{$ Interpretasi } \\ $0-0,20 &$ Sangat Rendah \\ $0,21-0,40 &$ Rendah \\ $0,41-0,60 &$ Cukup \\ $0,61-0,80 &$ Tinggi \\ $0,81-1,00 &$ Sangat Tinggi \end{aligned}

\subsubsection{Reliabilitas Instrumen}

Sebuah tes dikatakan reliable apabila hasil-hasil tes tersebut menunjukkan ketepatan Rumus yang digunakan untuk mencari reliabilitas instrumen yaitu rumus K-R. 20 (Arikunto, 2012:115)

$$
r_{11}=\left(\frac{n}{n-1}\right)\left(\frac{S^{2}-\sum p q}{S^{2}}\right)
$$

Keterangan:

$r_{11}=$ reliabilitas tes secara keseluruhan

$\mathrm{n}=$ banyak butir soal (item)

$\mathrm{p}=$ proporsi subjek yang menjawab item dengan benar

$\mathrm{q}=$ proporsi subjek yang menjawab item dengan salah

$\sum \mathrm{pq}=$ jumlah hasil perkalian antara $\mathrm{p}$ dan $\mathrm{q}$

Interpretasi derajat reliabilitas disajikan dalam tabel berikut:

$$
\mathrm{S}=\text { Standar Deviasi dari tes }
$$

\section{Tabel 3.2}

Interpretasi Derajat Reliabilitas

\begin{tabular}{ll} 
Besar nilai $r_{11}$ & \multicolumn{1}{c}{ Interpretasi } \\
$0,91-1,00$ & Sangat Tinggi \\
$0,71-0,90$ & Tinggi \\
$0,41-0,70$ & Sedang \\
$0,21-0,40$ & Rendah \\
$0,00-0,20$ & Sangat Rendah \\
$r_{11}<0,00$ & Tidak Reliabel
\end{tabular}




\subsubsection{Indeks Kesukaran}

Soal yang baik adalah soal yang tidak terlalu sulit dan tidak terlalu mudah, soal yang mudah tidak dapat merangsang siswa untuk mempertinggi kemampuanya untuk menyelesaikan soal tersebut. Sebaliknya soal yang terlalu sulit menyebabkan siswa patah semangat. Menurut Arikunto (2012:208) untuk mengetahui tingkat kesukaran soal dapat digunakan rumus

$$
\mathrm{P}=\frac{\mathrm{B}}{\mathrm{JS}}
$$

Keterangan:

$\mathrm{P}=$ Indeks Kesukaran

$\mathrm{B}=$ Banyaknya siswa yang menjawab soal itu dengan benar

$\mathrm{JS}=$ Jumlah seluruh siswa peserta tes

Selanjutnya indeks kesukaran yang diperoleh diinterpretasikan dengan menggunakan kriteria sesuai dengan tabel 3.4 .

\section{Tabel 3.3}

\begin{tabular}{ll}
\multicolumn{2}{c}{ Klasifikasi Indeks Kesukaran } \\
Nilai IK & \multicolumn{1}{c}{ Interpretasi } \\
$\mathrm{IK}=0,00$ & Soal terlalu sukar \\
$0,00<\mathrm{IK} \leq 0,30$ & Soal sukar \\
$0,30<\mathrm{IK} \leq 0,70$ & Soal sedang \\
$0,70<\mathrm{IK} \leq 1,00$ & Soal mudah \\
$\mathrm{IK}=1,00$ & Soal terlalu muda
\end{tabular}

\subsubsection{Daya Pembeda}

Menurut Arikunto (2012:211) daya pembeda soal adalah kemampuan suatu soal untuk membedakan antara siswa yang pandai(berkemampuan tinggi) dengan peserta didik yang berkemampuan rendah.

Rumus yang digunakan untuk mengetahui daya pembeda (Arikunto, 2012:) adalah sebagai berikut:

Keterangan:

$$
\mathrm{DP}=\frac{\mathrm{JB}_{\mathrm{A}}-\mathrm{JB}_{\mathrm{B}}}{\mathrm{JS}_{\mathrm{A}}}
$$

$\mathrm{DP}=$ Daya Pembeda

$\mathrm{JB}_{\mathrm{A}}=$ Jumlah siswa kelompok atas yang menjawab soal dengan benar

$\mathrm{JB}_{\mathrm{B}}=$ jumlah siswa kelompok bawah yang menjawab soal dengan benar

$\mathrm{JS}_{\mathrm{A}}=$ Jumlah siswa kelompok atas

Selanjutnya koefisien daya pembeda yang diperoleh diinterpretasikan dengan menggunakan kriteria sesuai dengan tabel 3.5

\section{Tabel 3.4}

\section{Klasifikasi Daya Pembeda}

$\begin{array}{ll}\text { Nilai Daya Pembeda } & \text { Interpretasi } \\ \text { DP } \leq 0,00 & \text { Sangat Jelek } \\ 0,00<\mathrm{DP} \leq 0,20 & \text { Jelek } \\ 0,20<\mathrm{DP} \leq 0,40 & \text { Cukup } \\ 0,40<\mathrm{DP} \leq 0,70 & \text { Baik } \\ 0,70<\mathrm{DP} \leq & \text { Sangat Baik }\end{array}$




\subsubsection{Analisis Indeks Gain}

Analisis data skor gain ternormalisasi dilakukan untuk menguji hipotesis, jika kemampuan awal kelompok eksperimen I dan eksperimen II berbeda secara signifikan. Rumus indeks gain ternormalisasi menurut Meltzer (Handini, 2008:34) yaitu:

$$
\text { Indeks Gain }=\frac{\text { Skor Pos Test }- \text { Skor Pre Test }}{\text { SMI }- \text { Skor Pre Test }}
$$

Adapun untuk kriteria rendah, sedang dan tinggi mengacu pada kriteria Hake (Barka dalam Khususwanto, 2008:49), yaitu sebagai berikut:

\section{Tabel 3.5}

\section{Klasifikasi Indeks Gain}

$\begin{array}{ll}\text { Indeks Gain }<0,30 & : \text { Rendah } \\ 0,30 \leq \text { Indeks Gain } \leq & : \text { Sedang } \\ 0,70 & \\ \text { Indeks Gain }>0,70 & : \text { Tinggi }\end{array}$

Langkah-langkah pengujian yang ditempuh untuk data pretes, postes dan indeks gain adalah sebagai berikut:

a. Uji Normalitas

Uji normalitas dilakukan untuk mengetahui apakah data kedua kelas yaitu kelas ekperimen dan control mempunyai varians yang sama atau tidak. Jika kedua kelompok mempunya berasal dari populasi yang berdistribusi normal.

b. Uji Homogenitas

Uji homogenitas varians digunakan untuk mengetahui apakah kedua kelas mengetahui memiliki varians yang homogen atau tidak.

c. Jika data yang dianalisis berdistribusi normal dan homogen, maka untuk pengujian hipotesis dilakukan uji t.

d. Jika data yang dianalisis berdistribusi normal tetapi tidak homogen, maka untuk pengujian hipotesis dilakukan uji t'.

e. Jika salah satu atau kedua data yang dianalisis tidak berdistribusi normal, maka tidak dilakukan uji homogenitas sedangkan untuk pengujian hipotesis dilakukan uji statistik non parametrik, seperti uji Mann-Whitney.

\subsubsection{Analisis Deskriptif Persentase}

Metode analisis persentase digunakan untuk mengetahui tingkat persentase aktivitas guru per aspek dan kemapuan guru dalam pengelolaan pembelajaran ditentukan dengan perhitungan indeks persentase. Perhitungan indeks persentase dihitung dengan rumus sebagai berikut :

Keterangan :

$$
\%=\frac{n}{N} \times 100 \%
$$

$$
\begin{aligned}
& \% \quad \text { : Nilai Persentase atau hasil } \\
& \mathrm{n} \quad \text { : Jumlah Nilai yang diperoleh } \\
& \text { N : Jumlah Seluruh nilai totak (skor ideal) } \\
& \text { (Ali, 1993:184) }
\end{aligned}
$$


berikut

Langkah-langkah menggunkan rumus analisis deskriptif persentase adalah sebagai

Penentuan tabel kategori untuk observasi aspek pengelolaan pembelajaran :

Data maksimal $\quad=24 \times 4=96$

Data minimum $\quad=24 \times 1=24$

Range $\quad=$ Data $\max -$ data $\min$

$=96-24=72$

Kelas Interval $\quad=$ Range/Banyak kelas

$=72 / 4=18$

1. Persentase Maksimal $=\frac{4}{4} \times 100 \%=100 \%$

2. Persentase Minimum $=\frac{1}{4} \times 100 \%=25 \%$

3. Rentang Persentase $=100 \%-25 \%=75 \%$

4. Interval Persentase $\quad=\frac{75 \%}{4} \times 100 \%=19 \%$

Tabel 3.6 Interval Kelas dan Kategori Aspek Pengelolaan Pembelajaran

\begin{tabular}{|c|c|c|}
\hline Skor Interval & Interval & Kategori \\
\hline$<78-\leq 96$ & $\geq 82,00 \%-\leq 100,00 \%$ & Baik \\
\hline$<60-\leq 78$ & $\geq 63,00 \%-\leq 81,00 \%$ & Cukup Baik \\
\hline$<42-\leq 60$ & $\geq 44,00 \%-\leq 62,00 \%$ & Kurang Baik \\
\hline$<24-\leq 42$ & $\geq 25,00 \%-\leq 43,00 \%$ & Tidak Baik \\
\hline
\end{tabular}

\section{Hasil Analisis Dan Pembahasan}

Penelitian ini dilaksanakan Di SMK Negeri 7 Medan dengan populasi penelitian kelas X tahun ajaran 2015/2016. Kelas X terdiri dari 4 Kelas yaitu kelas X Ak1, Ak2, Ak3 dan X Ak4. Yang menjadi kelas eksperimen dalam penelitian ini adalah kelas AK1 sementara untuk kelas kontrol adalah kelas AK 4. Jenis Penelitian ini adalah Quasi Eksperimen (Satu Kelas Eksperimen dan Satu Kelas Pembanding atau Kontrol). Tahapan yang dilakukan adalah membagi subjek menjadi dua kelas, kemudian pada kelas eksperimen (Kelas XAk1) diberikan perlakuan (treatment) berupa pembelajaran dengan menggunakan media pembelajaran Quipper School Sedangkan pada kelas pembanding (Kelas XAk4) diberikan perlakukan (treatment) berupa pembelajaran konvensional.

Pelaksanaan pembelajaran pada tahap pertama dilaksanakan pada hari Selasa 8 September 2015 S/D Kamis 17 September 2015 . Namun sebelum pembelajaran dilaksanakan peneliti sudah memberikan Pre-Tes yang membutuhkan waktu 60 menit pada pertemuan sebelumnya yaitu pada hari kamis 3 September 2015 untuk mengetahui sejauh mana pengetahuan siswa terhadap pokok bahasan mengenai dasar-dasar akuntansi.

Proses awal pembelajaran pada kelas eksperimen adalah guru menjelaskan tentang model pembelajaran Quipper School dan memberikan apersepsi untuk mengetahui sejauh mana pengetahuan siswa terhadap pokok bahasan mengenai dasar-dasar akuntansi yaitu jurnal umum sampai pada laporan keuangan. Guru yang menjalankan proses kegiatan belajar mengajaranya sedangkan peneliti sebagai pengamat (observer) yang menilai aktivitas pembelajaran dan kemampuan pengelolaan pembelajaran.

Selanjutnya Guru menjalankan proses pembelajaran sesuai dengan RPP yang dibuat oleh 
tim peneliti. Proses pembelajaran untuk kelas eksperimen dilakukan di lab.Komputer dengan menggunakan aplikasi Quipper School, sedangkan proses pembelajaran untuk kelas kontrol dilakukan dikelas seperti biasa. Materi yang diajarkan adalah tentang jurnal umum,buku besar, neraca saldo dan laporan keuangan masing-masing satu kali pertemuan.

Hasil observasi pengelolaan pembelajaran dengan media Quipper School dapat dilihat pada tabel berikut :

Tabel 5.1 Hasil Observasi Pengelolaan Pembelajaran dengan media Quipper School

\begin{tabular}{|c|c|c|c|c|c|}
\hline \multirow[t]{2}{*}{ No } & \multirow[t]{2}{*}{ Aspek Yang Diamati } & \multicolumn{4}{|c|}{$\begin{array}{c}\text { Pembelajaran Dengan Media } \\
\text { Quipper School } \\
\end{array}$} \\
\hline & & Tahap 1 & Tahap 2 & Tahap 3 & Tahap 4 \\
\hline \multirow[t]{6}{*}{$\mathbf{A}$} & PERSIAPAN & & & & \\
\hline & $\begin{array}{l}\text { Guru mempersiapkan rencana pelaksanaan pembelajaran } \\
\text { (RPP) dengan seksama }\end{array}$ & 3 & 3 & 3 & 3 \\
\hline & $\begin{array}{l}\text { Tujuan pembelajarannya dinyatakan dalam kalimat yang } \\
\text { jelas dalam RPP }\end{array}$ & 3 & 3 & 3 & 3 \\
\hline & $\begin{array}{l}\text { Materi pembelajaran yang akan diberikan memiliki } \\
\text { kaitan atau dapat dikaitkan dengan materi pembelajaran } \\
\text { sebelumnya }\end{array}$ & 4 & 4 & 4 & 4 \\
\hline & Guru mempersiapkan media pembelajaran & 3 & 4 & 4 & 4 \\
\hline & $\begin{array}{l}\text { Guru memeriksa sambungan internet untuk proses } \\
\text { pembelajaran }\end{array}$ & 3 & 4 & 4 & 4 \\
\hline \multirow[t]{14}{*}{ II } & PELAKSANAAN PEMBELAJARAN & & & & \\
\hline & $\begin{array}{l}\text { Guru memotivasisiswa, menarik perhatian agar } \\
\text { mengikuti proses pembelajaran dengan baik }\end{array}$ & 3 & 4 & 4 & 4 \\
\hline & $\begin{array}{l}\text { Guru menjelaskan materi pembelajaran dengan teknik- } \\
\text { teknik tertentu sehingga jelas dan mudah dipahami siswa }\end{array}$ & 3 & 3 & 3 & 4 \\
\hline & $\begin{array}{l}\text { Pembelajaran dilaksanakan dalam langkah-langkah dan } \\
\text { urutan yang logis }\end{array}$ & 3 & 3 & 3 & 4 \\
\hline & $\begin{array}{lll}\text { Selama proses pembelajaran guru memberikan } \\
\text { kesempatan untuk bertanya kepada siswa }\end{array}$ & 3 & 3 & 3 & 4 \\
\hline & $\begin{array}{l}\text { Apabila siswa bertanya, maka guru memberikan jawaban } \\
\text { dengan jelas dan memuaskan }\end{array}$ & 3 & 3 & 3 & 4 \\
\hline & $\begin{array}{l}\text { Guru selalu mengajak siswa untuk menyimpulkan } \\
\text { pembelajaran pada akhir kegiatan atau akhir sesi tertentu }\end{array}$ & 3 & 4 & 4 & 4 \\
\hline & $\begin{array}{l}\text { Pembelajaran dilakukan secara bervariasi selama alokasi } \\
\text { waktu yang tersedia, tidak monoton dan membosankan }\end{array}$ & 3 & 4 & 4 & 4 \\
\hline & $\begin{array}{l}\text { selama pembelajaran berlangsung guru tidak hanya } \\
\text { berada pada posisi tertentu tetapi bergerak secara } \\
\text { dinamis di dalam kelasnya }\end{array}$ & 3 & 4 & 4 & 4 \\
\hline & $\begin{array}{l}\text { Apabila tampak ada siswa yang membutuhkan } \\
\text { bantuannya di bagian-bagian tertentu kelas, maka guru } \\
\text { harus bergerak dan menghampiri secara berimbang dan } \\
\text { tidak terfokus hanya pada beberapa gelintir siswa saja }\end{array}$ & 3 & 4 & 4 & 4 \\
\hline & $\begin{array}{l}\text { Selama pembelajaran berlangsung guru memberikan } \\
\text { reinforcement (penguatan) kepada siswa-siswanya } \\
\text { dengan cara yang positif }\end{array}$ & 4 & 4 & 4 & 4 \\
\hline & $\begin{array}{l}\text { Ilustrasi dan contoh dipilih secara hati-hati sehingga } \\
\text { benar-benar efektif dan bukannya malah membuat } \\
\text { bingung siswa }\end{array}$ & 3 & 3 & 3 & 4 \\
\hline & $\begin{array}{l}\text { Media pembelajaran di dalam pelaksanaan pembelajaran } \\
\text { digunakan secara efektif }\end{array}$ & 3 & 3 & 4 & 4 \\
\hline & Latihan diberikan secara efektif & 3 & 3 & 3 & 4 \\
\hline \multirow[t]{4}{*}{ III } & KAREKTERISTIK PRIBADI GURU & & & & \\
\hline & Guru sabar terutama untuk memancing respon siswa & 3 & 3 & 4 & 4 \\
\hline & $\begin{array}{l}\text { Guru berupaya memancing siswa agar terlibat aktif } \\
\text { dalam pembelajaran }\end{array}$ & 3 & 4 & 4 & 4 \\
\hline & Guru bersikap tegas dan jelas & 3 & 3 & 4 & 4 \\
\hline
\end{tabular}




\begin{tabular}{|l|l|l|l|l|l|}
\hline & Penampilan guru menarik dan tidak membosankan & 3 & 4 & 4 & 4 \\
\hline & Guru menggunakan bahasa yang baik dan berterima & 3 & 3 & 3 & 4 \\
\hline $\begin{array}{l}\text { Guru selalu menunjukkan bahwa ia adalah seorang yang } \\
\text { selalu punya inisiatif,kreatif, dan berprakarsa }\end{array}$ & 3 & 3 & 4 & 4 \\
\hline Total & 74 & 83 & 87 & 94 \\
\hline & \%Kemampuan Pengelolaan Pembelajaran & $74 \%$ & $86 \%$ & $90 \%$ & $97 \%$ \\
\hline
\end{tabular}

Sesuai tabel diketahui bahwa aktivitas pengelolaan pembelajaran tahap pertama dengan model pembelajaran Quipper School memperoleh skor 74 atau 74\% dengan kategori cukup baik. Sebagian dari perencanaan sudah terlaksana dengan baik selama proses pembelajaran.

Pembelajaran dengan media pembelajaran Quipper School yang terakhir di laksanakan pada hari Kamis, 17 Septemebr 2015 Pada pertemuan ini, guru mereview materi yang telah disampaikan. Dalam pelaksanaan pembelajaran, guru telah melaksanakan kegiatan pembelajaran dengan cukup baik, dapat dilihat peningkatan pada hari ke empat dengan skor 94 atau $97 \%$ hal ini didukung karena siswa telah terbiasa dengan pembelajaran Quipper School yang telah dilaksanakan pada tahap pertama, kedua dan ketiga. Pada kegiatan akhir guru dan siswa membahas mengenai laporan keuangan dan menyimpulan materi serta memberi tahu pada pertemuan berikutnya di adakan post-test, untuk mengetahui hasil belajar siswa setelah menerapkan pembelajaran dengan media Quipper School.

\section{Kefektifan Pembelajaran konvensional}

Pembelajaran pada kelas kontrol menerapkan model pembelajaran konvensional atau yang sering digunakan oleh guru yaitu dengan ceramah, latihan serta pengamatan. Proses pembelajaran konvensional dilakukan dalam 4 kali pertemuan yaitu pada tanggal $8,10,15,17$ September 2015, sebagian besar waktu belajar mengajar digunakan untuk menjelaskan materi, setelah menjelaskan materi kemudian guru memberikan latihan soal. Setelah siswa mengerjakan maka hasilnya dibahas bersama-sama oleh guru.

Pembelajaran pertama dilaksanakan pada hari Selasa, 8 September 2015 namun sebelumnya dilaksanakan pre-test pokok bahasan Jurnal umum sampai kepada laporan keuangan terlebih dahulu pada Hari Selasa, 3 September 2015 yang membutuhkan waktu 60 menit untuk mengetahui sejauh mana pengetahuan siswa terhadap pokok bahasan jurnal umum dan laporan keuangan dan menjelaskan tujuan penelitian.

Tabel Hasil Observasi Pengelolaan Pembelajaran Konvensional

\begin{tabular}{|c|c|c|c|c|c|}
\hline \multirow[b]{2}{*}{ No } & \multirow[b]{2}{*}{ Aspek Yang Diamati } & \multicolumn{4}{|c|}{ Pembelajaran Konvensional } \\
\hline & & Tahap 1 & $\begin{array}{l}\text { Tahap } \\
2\end{array}$ & $\begin{array}{l}\text { Tahap } \\
3\end{array}$ & $\begin{array}{l}\text { Tahap } \\
4\end{array}$ \\
\hline \multirow[t]{6}{*}{$\mathbf{I}$} & PERSIAPAN & & & & \\
\hline & $\begin{array}{l}\text { Guru mempersiap kan rencana } \\
\text { pembelajaran (RPP) dengan seksama }\end{array}$ & 3 & 3 & 3 & 3 \\
\hline & $\begin{array}{l}\text { Tujuan pembelajarannya dinyatakan dalam kalimat yang } \\
\text { jelas dalam RPP }\end{array}$ & 3 & 3 & 3 & 4 \\
\hline & $\begin{array}{l}\text { Materi pembelajaran yang akan diberikan memiliki } \\
\text { kaitan atau dapat dikaitkan dengan materi pembelajaran } \\
\text { sebelumnya }\end{array}$ & 3 & 3 & 4 & 4 \\
\hline & Guru mempersiapkan media pembelajaran & 3 & 3 & 3 & 3 \\
\hline & Guru memastikan kelengkapan & 3 & 3 & 4 & 4 \\
\hline \multirow[t]{4}{*}{ II } & PELAKSANAAN PEMBELAJARAN & & & & \\
\hline & $\begin{array}{l}\text { Guru memotivasisiswa, menarik perhatian agar } \\
\text { mengikuti proses pembelajaran dengan baik }\end{array}$ & 3 & 3 & 4 & 4 \\
\hline & $\begin{array}{l}\text { Guru menjelaskan materi pembelajaran dengan teknik- } \\
\text { teknik tertentu sehingga jelas dan mudah dipahami siswa }\end{array}$ & 3 & 3 & 3 & 3 \\
\hline & $\begin{array}{l}\text { Pembelajaran dilaksanakan dalam langkah-langkah dan } \\
\text { urutan yang logis }\end{array}$ & 3 & 3 & 3 & 3 \\
\hline
\end{tabular}




\begin{tabular}{|c|c|c|c|c|c|}
\hline & $\begin{array}{l}\text { Selama proses pembelajaran guru memberikan } \\
\text { kesempatan untuk bertanya kepada siswa }\end{array}$ & 3 & 3 & 3 & 3 \\
\hline & $\begin{array}{l}\text { Apabila siswa bertanya, maka guru memberikan jawaban } \\
\text { dengan jelas dan memuaskan }\end{array}$ & 3 & 3 & 3 & 3 \\
\hline & $\begin{array}{l}\text { Guru selalu mengajak siswa untuk menyimpulkan } \\
\text { pembelajaran pada akhir kegiatan atau akhir sesi tertentu }\end{array}$ & 3 & 3 & 4 & 4 \\
\hline & $\begin{array}{l}\text { Pembelajaran dilakukan secara bervariasi selama alokasi } \\
\text { waktu yang tersedia, tidak monoton dan membosankan }\end{array}$ & 3 & 3 & 4 & 4 \\
\hline & $\begin{array}{l}\text { selama pembelajaran berlangsung guru tidak hanya } \\
\text { berada pada posisi tertentu tetapi bergerak secara } \\
\text { dinamis di dalam kelasnya }\end{array}$ & 3 & 4 & 4 & 4 \\
\hline & $\begin{array}{l}\text { Apabila tampak ada siswa yang membutuhkan } \\
\text { bantuannya di bagian-bagian tertentu kelas, maka guru } \\
\text { harus bergerak dan menghampiri secara berimbang dan } \\
\text { tidak terfokus hanya pada beberapa gelintir siswa saja }\end{array}$ & 3 & 3 & 4 & 4 \\
\hline & $\begin{array}{l}\text { Selama pembelajaran berlangsung guru memberikan } \\
\text { reinforcement (penguatan) kepada siswa-siswanya } \\
\text { dengan cara yang positif }\end{array}$ & 3 & 4 & 4 & 4 \\
\hline & $\begin{array}{l}\text { Ilustrasi dan contoh dipilih secara hati-hati sehingga } \\
\text { benar-benar efektif dan bukannya malah membuat } \\
\text { bingung siswa }\end{array}$ & 3 & 3 & 3 & 4 \\
\hline & $\begin{array}{l}\text { Media pembelajaran di dalam pelaksanaan pembelajaran } \\
\text { digunakan secara efektif }\end{array}$ & 3 & 3 & 3 & 4 \\
\hline & Latihan diberikan secara efektif & 3 & 3 & 3 & 4 \\
\hline III & KAREKTERISTIK PRIBADI GURU & & & & \\
\hline & Guru sabar terutama untuk memancing respon siswa & 3 & 3 & 3 & 4 \\
\hline & $\begin{array}{l}\text { Guru berupaya memancing siswa agar terlibat aktif } \\
\text { dalam pembelajaran }\end{array}$ & 3 & 3 & 4 & 4 \\
\hline & Guru bersikap tegas dan jelas & 3 & 3 & 4 & 4 \\
\hline & Penampilan guru menarik dan tidak membosankan & 3 & 3 & 4 & 4 \\
\hline & Guru menggunakan bahasa yang baik dan berterima & 3 & 3 & 3 & 4 \\
\hline & $\begin{array}{l}\text { Guru selalu menunjukkan bahwa ia adalah seorang yang } \\
\text { selalu punya inisiatif,kreatif, dan berprakarsa }\end{array}$ & 3 & 3 & 3 & 4 \\
\hline & Total & 72 & 77 & 82 & 90 \\
\hline & \% KemampuanPengelolaanPembelajaran & $75 \%$ & $80 \%$ & $85 \%$ & $93 \%$ \\
\hline
\end{tabular}

Sesuai tabel 4.2 diketahui bahwa aktivitas pengelolaan pembelajaran yang dilakukan oleh guru selama kegiatan pembelajaran konvensional pada tahap pertama dengan skor 72 , tingkat persentase $75 \%$ dengan kategori cukup baik. Sebagian dari perencanaan sudah terlaksana dan guru mampu mengelola pembelajaran konvensional. Dan perencanaan pembelajaran semakin meningkat pada tahap keempat yaitu dengan skor 90 atau $93 \%$.

Aktivitas siswa pada kelas kontrol cenderung monoton karena proses pembelajarannya tidak ada variasi. Dimulai dengan guru memberi kesempatan pada siswa untuk bertanya dan menjawab pertanyaan, guru juga berkeliling kelas untuk mengamati siswa cenderung bosan dan terlihat pasif dalam pembelajaran, sehingga guru kurang bisa mengontrol sejauh mana pemahaman siswa terhadap materi yang diberikan.

Pembelajaran konvensional berbeda dengan pembelajaran dengan media pembelajaran Quipper School. Pada pembelajaran konvensional tidak ada aplikasi pendukung pelajaran sehingga ketertarikan siswa akan pelajaran yang diberikan tidak telalu baik.

\section{Tekhnik Analisis Data Pengujian Instrumen Penelitian}

Sebelum soal hasil belajar (soal pre-test dan post-test) diberikan pada kelas kontrol dan kelas eksperimen di SMK Negeri 7 Medan, instrumen tersebut diuji cobakan pada kelas X SMK Negeri 1 Medan sebanyak 40 soal untuk diuji validitas dan reliabilitas butir soal. Soal hasil belajar untuk eksperimen dalam bentuk pilihan ganda dengan 4 opsi jawaban A,B,C dan D.

Vol : 8, No:2, 2020

Jurnal Akuntansi dan Perpajakan Indonesia UNIMED 
Setelah diperoleh data soal hasil belajar oleh siswa, kemudian hasilnya diuji validitas dan reliabilitasnya. Soal hasil belajar yang telah di uji validitas dan uji reliabilitas tersebut digunakan dalam pengambilan data penelitian.

Hasil uji coba instrumen adalah sebagai berikut:

\section{Validitas butir soal}

Perhitungan validitas butir soal berdasarkan Rumus Korelasi Product Moment dengan mengunakan bantuan Program Excel, didapatkan nilai validasi antara -0,148 sampai dengan 0,853 . Hasil perhitungan tersebut kemudian dibandingkan dengan tabel $r$ product momentpada taraf signifikan 5\%. Dari hasil perbandingan taraf signifikan 5\% tersebut menunjukkan bahwa dari 40 butir soal pilihan ganda yang telah di telaah, terdapat 28 butir soal yang valid.

\section{Reliabilitas butir}

Hasil perhitungan reliabilitas berdasarkan rumus KR-20 dengan menggunakan bantuan Program Excel didapatkan nilai reliabilitas 0,914. Hal tersebut menunjukkan bahwa tes pilihan ganda ini memiliki tingkat reliabilitas yang sangat tinggi. Artinya tes ini menghasilkan skor yang ajeg/konsisten dimana skor yang dihasilkan relatif tidak berubahmeskipun waktu dan situasi saat tes digunakan berbeda-beda.

\section{Taraf kesukaran}

Dari hasil uji coba terhadap 40 siswa kelas X SMK Negeri 1 Medan didapatkan perolehan skor tertinggi 39 dan perolehan skor terendah 18. Dari hasil analisis data pada uji instrumen tersebut didapatkan 14 soal sedang, 25 soal mudah dan 1 soal terlalu mudah. Persentase tingkat kesukaran pada soal-soal tes pilihan ganda ini yaitu 35\% soal sedang, 62,5\% mudah dan $2,5 \%$ soal terlalu mudah.

\section{Daya pembeda}

Dari hasil analisis daya pembeda butir soal yan diujicobakan didapatkan variasi tingkat daya pembeda antara -0,09 sampai dengan 0,73. Jadi butir soal yang diujicobakan mempunyai variasi 1 soal sangat jelek, 9 soal jelek, 11 soal cukup, 14 soal baik dan 5 soal yang sangat baik. Persentase daya pembeda pada soal-soal tes ini yaitu 2,5\% soal sangat jelek, 22,5\% soal jelek, $27,5 \%$ soal cukup, $35 \%$ soal baik dan $12,5 \%$ soal sangat baik. Indeks daya pembeda mulai dari soal cukup sampai soal sangat baik dapat dikategorikan baik. Sedangkan untuk indeks daya pembeda soal sangat jelek sampai soal jelek dikategorikan rendah. Jadi sebanyak $75 \%$ soal pada tes pilihan ganda ini memiliki indeks daya pembeda baik, yang artinya soal tersebut mampu membedakan peserta didik mana yang belajar dan tidak belajar atau dengan kata lain dapat membedakan antara peserta didik yang menguasai dan yang tidak menguasai materi. Sedangkan $25 \%$ soal pada tes pilihan ganda ini memiliki indeks daya pembeda rendah. Hal tersebut menunjukkan bahwa soal-soal tersebut tidak dapat membedakan antara peserta didik yang menguasai materi dengan yang tidak menguasai materi.

\section{Deskripsi Hasil Penelitian}

Kelompok eksperimen memiliki rata-rata skor pre-test sebesar 21,875dan rata-rata skor post-test sebesar 24,950 dengan indeks gain rata-rata 0,573.Kelompok kontrol memiliki rata-rata skor pre-test sebesar 20,150 dan rata-rata skor post-test sebesar 23,375 dengan indeks gain ratarata 0,436 .

\section{Analisis Data}

Analisis digunakan untuk mengetahui kemampuan siswa sebelum adanya perlakuan (treatment) bertujuan untuk mengetahui apakah kelas eksperimen dan kelas kontrol berawal dari keadaan yang setara. Data yang digunakan dalam analisis ini adalah hasil pre-tes dan post-test.

\section{Uji Normalitas dan Homogenitas}


2. Sebelum dilakukan analisis uji F perlu dilakukan uji pra syarat analisis yaitu uji normalitas dan uji homogenitas varian. Hasil uji normalitas dan uji homogenitas varian adalah sebagai berikut:

\section{a. Uji Normalitas}

Pada penelitian ini untuk mengetahui normal atau tidaknya data penelitian digunakan uji Lilliefors pada tingkat signifikan 5\%. Distribusi data penelitian dikatakan normal jika hasil analisis diperoleh $p>0,05$, sedangkan jika nilai $p<0,05$ menunjukkan bahwa distribusi data penelitian tidak normal. Hasil uji normalitas memerikan hasil seperti pada tabel 1.

Tabel 5.3 Ringkasan Hasil Uji Normalitas Data Penelitian

\begin{tabular}{|l|l|l|l|}
\hline \multicolumn{1}{|c|}{ Kelompok } & Nilai Lilliefors & p & Kesimpulan \\
\hline Kelompok Eksperimen & & & \\
\hline Pre-Test & 0,136 & 0,060 & Normal \\
\hline Post-Test & 0,130 & 0,087 & Normal \\
\hline Indeks Gain & 0,120 & 0,152 & Normal \\
\hline Kelompok Kontrol & & & \\
\hline Pre-Test & 0,125 & 0,114 & Normal \\
\hline Post-Test & 0,128 & 0,096 & Normal \\
\hline Indeks Gain & 0,141 & 0,064 & Normal \\
\hline
\end{tabular}

*Data berdistribusi normal/tidak normal dengan $p>0,05$

Pada tabel diketahui nilai pre-test dan post-test pada kedua kelompok maupun indeks gainnya memiliki nilai $p>0,05$, menunjukkan data memiliki sebaran normal.

b. Uji Homogenitas

Uji homogenitas digunakan untuk mengetahui apakah kedua kelompok data yang akan dianalisis berasal dari populasi yang homogen atau tidak. Pada penelitian uji homogenitas dilakukan menggunakan teknik Levene Test. Dikatakan memenuhi asumsi homogenitas atau berasal dari populasi yang memiliki varian homogen jika nilai $p>0,05$. Hasil uji homogenitas dapat diringkas pada tabel 2 .

Tabel Ringkasan Hasil Uji Homogenitas

\begin{tabular}{|l|l|l|l|}
\hline lompok & lai F & & simpulan \\
\hline or Pre-Test & 95 & $\$ 84$ & mogen \\
\hline or Post-Test & 55 & $\$ 02$ & mogen \\
\hline in Ternormalisasi & $\$ 85$ & $\$ 37$ & mogen \\
\hline
\end{tabular}

Berdasarkan tabel diketahui hasil uji homogenitas skor pre-test, post-test dan indeks gainnya memiliki $p>0,05$. Hal ini menunjukkan bahwa data penelitian memenuhi asumsi homogenitas yaitu berasal dari kelompok yang memiliki varians homogen.

\section{Analisis Data Peningkatan Hasil Belajar Siswa}

Data peningkatan hasil belajar siswa dihitung dari gain ternormalisasi untuk mengukur peningkatan hasil belajar sebelum dan sesudah penggunaan Quipper School. Indeks gain diperoleh dari pembagain antara nilai post-test dikurangi nilai pre-test dengan nilai maksimum ideal dikurangi nilai pre-test siswa.

Tabel 5.5 Statistik Deskriptif Data Indeks Gain

\begin{tabular}{|l|l|l|l|l|l|}
\hline & N & Min & Max & Mean & Std. Dev \\
\hline
\end{tabular}




\begin{tabular}{|l|l|l|l|l|l|}
\hline Eksperimen & 40 & 0,11 & 1,00 & 0,573 & 0,268 \\
\hline Kontrol & 40 & 0,08 & 0,86 & 0,436 & 0,236 \\
\hline
\end{tabular}

Berdasarkan data diatas, dapat dilihat bahwa rata-rata nilai indeks gain kelas eksperimen 0,573 dengan simpangan baku 0,268 sedangkan rata-rata nilai indeks gain kelas kontrol 0,436 dengan simpangan baku 0,236. Berdasarkan tabel di atas bahwa rata-rata nilai indeks gain kelas eksperimen dan kelas kontrol berbeda cukup jauh. Kategori perolehan indeks gain oleh kelas eksperimen dan kelas kontrol dapat dilihat pada Tabel 2.

Tabel 5.6 Interpretasi Indeks Gain

\begin{tabular}{|l|l|l|}
\hline Kelas & $\begin{array}{l}\text { Nilai } \\
(\mathrm{g})\end{array}$ & Interpretasi \\
\hline Eksperimen & 0,573 & Sedang \\
\hline Kontrol & 0,436 & Sedang \\
\hline
\end{tabular}

1) Uji Normalitas Indeks Gain

Tabel 5.6 Hasil Uji Normalitas Gain

\begin{tabular}{|l|l|l|l|}
\hline & \multicolumn{3}{|l|}{ Lilliefors } \\
\hline & Statistic & Df & Sig. \\
\hline Eksperimen & 0,120 & 40 & 0,152 \\
\hline Kontrol & 0,141 & 40 & 0,064 \\
\hline
\end{tabular}

Berdasarkan perhitungan uji normalitas kelas eksperimen di dapat niliai signifikansi 0,152 . Maka data kelas eksperimen berdistribusi normal karena nilainya lebih besar dari nilai signifikansi sebesar 0,05. Uji normalitas kelas kontrol di dapat nilai signifikansi 0,064. Maka data kelas kontrol berdistribusi normal karena nilainya lebih besar dari nilai signifikansi sebesar 0,05 .

\section{2) Uji Anova Satu Jalur}

Dalam pengujian hipotesis data yang digunakan adalah nilai gain. Hal ini dilakukan untuk mengetahui adanya perbedaan pada kemampuan akhir setelah peserta didik diberi perlakuan. Untuk mengetahui terjadi tidaknya perbedaan perlakuan maka digunakan uji Anova satu jalur, pengujian hipotesis adalah sebagai berikut.

Keterangan:

$$
\begin{aligned}
& \mathrm{H}_{0}: \mu_{1} \leq \mu_{2} \\
& \mathrm{H}_{\mathrm{a}}: \mu_{1}>\mu_{2}
\end{aligned}
$$

$\mu_{1}=$ Rata - rata hasil belajar akuntansi dengan menggunakan Quipper School.

$\mu_{2}=$ Rata - rata hasil belajar akuntansi tanpa menggunakan Quipper School.

Kriteria pengambilan keputusan yang digunakan adalah sebagai berikut:

- Jika nilai signifikansi (sig) $<0,05$, maka $\mathrm{H}_{0}$ ditolak.

- Jika nilai signifikansi (sig) $>0,05$, maka $\mathrm{H}_{0}$ diterima.

\section{Tabel 5.8 Hasil Uji Anova Satu Jalur}

\section{ANOVA}

Gain

\begin{tabular}{|l|l|l|l|l|l|}
\hline & Sum of Squares & Df & Mean Square & F & Sig. \\
\hline $\begin{array}{l}\text { Between } \\
\text { Groups }\end{array}$ & 0,752 & 1 & 0,752 & 11,712 & 0,001 \\
\hline Within Groups & 5,011 & 78 & 0,064 & & \\
\hline Total & 5,763 & 79 & & & \\
\hline
\end{tabular}

Berdasarkan perhitungan tersebut diperoleh bahwa nilai signifikansi Anova $=0,001$ lebih kecil dari 0,05 yang menandakan bahwa $\mathrm{H}_{0}$ ditolak atau $\mathrm{H}_{\mathrm{a}}$ diterima. Jadi dapat disimpulkan 
bahwa rata-rata hasil belajar akuntansi dengan menggunakan Quipper School lebih baik daripada rata-rata hasil belajar akuntansi tanpa menggunakan Quipper School.

\subsection{PEMBAHASAN}

Hasil belajar adalah kemampuan yang dimiliki siswa setelah ia menerima pengalaman belajarnya (Sudjana, 2010:22). Hasil belajar siswa dapat digunakan untuk mengetahui tingkat pemahaman siswa terhadap materi pelajaran. Penelitian diawali dengan pemberian pre-test pada kelas kontrol maupun kelas ekperimen untuk mengetahu kemampuan awal siswa terhadap materi pengantar akuntansi perusahaan jasa. Setelah pelaksanaan pre-test kemudian data pre-test diuji normalitas dan uji homogenitas sebagai uji prasyarat untuk uji selanjutnya.

Kelas eksperimen memiliki kemampuan awal rata-rata 21,875 sedangkan kelas kontrol mencapai kemampuan rata-rata 20,150. Hal ini dapat di artikan bahwa nilai rata-rata kedua kelas tidak jauh berbeda. Dari perhitungan uji homogenitas diperoleh nilai $P>0.05$ yaitu untuk skor Pre-tes $0.184>0.05$. maka kesimpulannya sampel mempunyai varians yang sama (homogen).

Setelah pemberian pre-test pada kedua kelas dilanjutkan dengan pelaksanaan pembelajaran dengan materi jurnal umum sampai dengan laporan keuangan pada perusahaan jasa. Dalam penyampaian materi tersebut kedua kelas diberi pembelajaran yang berbeda, y akni pembelajaran quipper school pada kelas eksperimen dan pembelajaran konvensional pada kelas kontrol. Hasil penelitian ini menunjukkan bahwa ada pengaruh media pembelajaran Quipper School terhadap hasil belajar siswa akuntansi di SMK Negeri 7 Medan. Hasil penelitian ini menunjukkan bahwa hasil belajar akuntansi siswa yang menggunakan media pembelajaran Quipper School lebih baik daripada hasil belajar akuntansi siswa dengan pembelajaran konvensional, ini dapat dilihat dari hasil Uji Anova satu Jalur yang menunjukkan nilai signifikansi Anova $<0.05$ yaitu $0.001<0.005$ yang berarti bahwa $\mathrm{H}_{0}$ ditolak atau $\mathrm{H}_{\mathrm{a}}$ diterima. Jadi dapat disimpulkan bahwa rata-rata hasil belajar akuntansi dengan menggunakan Quipper School lebih baik daripada rata-rata hasil belajar akuntansi tanpa menggunakan Quipper School.

Perbedaan ini bukan merupakan kebetulan saja dan bukan karena perbedaan karakteristik dan kemampuan awal siswa pada kedua kelas tersebut, hal ini disebabkan pemberian perlakuan (treatment) dengan menggunakan media pembelajaran Quipper School pada kelas eksperimen.

Kelebihan-kelebihan pada model pembelajaran Quipper School sehingga dapat berpengaruh terhadap hasil belajar siswa karena Quipper School mampu menciptakan pembelajaran yang aktif, inovatif, kreatif, menyenangkan bagi siswa selama proses pembelajaran. Pembelajaran yang aktif akan membuat siswa lebih bersemangat dan termotivasi untuk mengikuti kegiatan pembelajaran di dalam kelas sehingga akan berpengaruh terhadap hasil yang diperoleh. Kelebihan lain dari pembelajaran Quipper School adalah fitur-fitur yang terdapat di dalamnya sangat membantu siswa dalam memahami materi akuntansi, seperti saat siswa mengerjakan soalsoal latihan, mereka akan langsung mengetahui skor soal yang dikerjakan ataupun skor yang salah. Dan orang tua siswa juga dapat memantau perkembangan belajar anak mereka melalui Quipper School karena orang tua dapat mendaftar melalui link orang tua yang disediakan di Quipper School Indonesia.

Sedangkan pembelajaran akuntansi yang selama ini diterapkan dengan menggunakan pembelajaran konvensional membuat siswa kurang menguasai materi secara keseluruhan. Hal ini disebabkan siswa merasa bosan dan tidak bisa menemukan jawaban yang sebenarnya tanpa bantuan guru sehingga siswa cenderung pasif.

\section{Kesimpulan}

Berdasarkan hasil penelitian pengaruh Media pembelajaran (quipper School) terhadap Hasil Belajar Siswa Akuntansi Kelas X SMK Negeri 7 Medan diperoleh kesimpulan dan saran sebagai berikut : 
1. Penerapan media pembelajaran dengan menggunakan Quipper School siswa kelas X SMK 7 Negeri Medan dilaksanakan sebanyak enam kali pertemuan. Dalam setiap pertemuan dilaksanakan fase-fase berupa menumbuhkan rasa percaya diri dalam diri siswa, menumbuhkan dan memelihara minat siswa, mengevaluasi hasil belajar siswa, memberikan penguatan kepada siswa. Data yang diperoleh kemudian diolah sehingga mendapat kesimpulan bahwa penerapan model pembelajaran Quipper berjalan lancar dan membawa dampak positif bagi peningkatan hasil belajar siswa akuntansi kelas X. Walaupun berdampak positif masih terdapat kekuarangan dalam penerapan media pembelajaran quipper school dalam meningkatkan hasil belajar siswa kelas X di SMK Negeri 7 medan.

2. Rata-rata hasil belajar peserta didik yang menggunakan model pembelajaran Quiiper School lebih baik daripada rata-rata hasil belajar peserta didik yang menggunakan model pembelajaran konvensional. Kesimpulan ini didasarkan pada hasil akhir rata-rata siswa dimana rata-rata siswa dengan pembelajaran dengan media pembelajaran Quipper School adalah signifikansi Anova $=0,001$ lebih kecil dari 0,05 yang menandakan bahwa $\mathrm{H}_{0}$ ditolak atau $\mathrm{H}_{\mathrm{a}}$ diterima. Jadi dapat disimpulkan bahwa rata-rata hasil belajar akuntansi dengan menggunakan Quipper School lebih baik daripada rata-rata hasil belajar akuntansi tanpa menggunakan Quipper School.

3. Pembelajaran dengan menggunakan media pembelajaran quipper school perlu dikembangkan untuk diterapkan pada materi pokok lainnya, karena dengan adanya variasi pembelajaran dapat membuat peserta didik tidak jenuh dan merasa senang dalam mengikuti pelajaran. Dan pembelajaran Quipper School membutuhkan intensitas perhatian lebih banyak agar tujuan pembelajaran tercapai sesuai dengan alokasi waktu yang telah di tetapkan

\section{Referensi}

Ali, Mochmad. 2009. Penelitian Pendidikan Prosedur dan Strategi Bandung : Angkasa.

Arikunto Suharsimi. 2012. Dasar-Dasar Evaluasi Pendidikan. Bumi Aksara: Jakarta

Asror, Bisrul Mifachul. 2011. Pengembangan Media Pembelajaran Audiovisualpada Pokok Bahasan Laporan Keuangan Perusahaan Jasa di SMA Negeri 3Blitar.Skripsi tidak diterbitkan. Malang: Fakultas Ekonomi. UniversitasNegeri Malang.

Asnewastari.2006. Keefektifan Media Pembelajaran Dalam MeningkatkanPrestasi Belajar Siswa Pada Mata Pelajaran Akuntansi.Jurnal IlmuPendidikan Online. (Diakses 29 April 2015)

Buku panduan Quipper School Tahun 2010 (Online).

Daryanto.(2012). Model Pembelajaran Inovatif. Dalam Susilo. (2013). Rendahnya Prestasi Belajar Siswa. http://pandek29.blogspot.com/2013/02/rendahnya-prestasi-belajar-siswa.html. (Diakses 29 April 2015).

Dimyati dan Mudjiono.2009.Belajar dan Pembelajaran. Jakarta: Rineka Cipta.

Hanum, S.N. 2013.keefektifan e-learning sebagai media pembelajaran (studi evaluasi model pembelajran e-learning SMK Telkom Sandhy Putra). Purwekorto: [online] Jurnal pendidikan Vokasi,vol 3, Nomor 1:

Harahap, Sofyan Syahri. 2012. Teori Akuntansi. Jakarta: Rajawali Pers.

Mulyani,W. 2013. Pengaruh media pembelajaran berbasis e-learning terhadap hasil belajar siswa.Jakarta:[online]. http://respitory.uinjkt.ac.id/dsapce/bitstream/../wiwi.pd.di akses 29 April 2015.

Vol : 8, No : 2, 2020

Jurnal Akuntansi dan Perpajakan Indonesia UNIMED 
Purnama, S Edy. 2009. Optimalisasi Prestasi Belajar Matematika MelaluiPembelajaran dengan Media CD Interaktif (Multimedia) Bagi SiswaKelas 7-C SMP Negeri 1 Sruweng Kabupaten Kebumen.JurnalPendidikan, 5(1):92-99.

Sudjana, Nana. 2009. Penilaian Hasil Proses Belajar Mengajar.Bandung: Remaja Rosdakarya.

Slameto. 2010. Belajar dan Faktor-faktor yang Mempengaruhinya. Jakarta: Rineka Cipta.

Weygandt, dkk. 2011. Financial Accounting 6thEdition. United Stated: Wiley. 